\title{
В.В. Кондрашин
}

\section{О ДОСТИЖЕНИЯХ И ПРОБЛЕМАХ СОВРЕМЕННОЙ ОТЕЧЕСТВЕННОЙ ИСТОРИОГРАФИИ КРЕСТЬЯНСКОГО ПОВСТАНЧЕСКОГО ДВИЖЕНИЯ В РОССИИ В ГОДЫ ГРАЖДАНСКОЙ ВОЙНЫ}

(C) Кондрашин Виктор Викторович - доктор исторических наук, профессор, главный научный сотрудник, руководитель Центра экономической истории, Институт российской истории РАН, 117292, Российская Федерация, г. Москва, ул. Дмитрия Ульянова, 19.

E-mail: vikont37@yandex.ru. ORCID: https://orcid.org/0000-0001-7552-9265

\begin{abstract}
АННОТАЦИЯ
В статье анализируются достижения и проблемы в области изучения отечественными исследователями истории крестьянского повстанческого движения в России в годы Гражданской войны. Акцентируется внимание на наиболее значимых ее аспектах.

Рассматриваются результаты научных проектов по истории крестьянского движения в России в годы Гражданской войны, осуществленных под руководством А.В. Посадского. Указывается, что в изданиях проекта дан комплексный и сравнительно-исторический анализ всех наиболее известных фактов крестьянского повстанчества в России в годы Гражданской войны против политики советской власти.

Автор статьи анализирует труды еще одного крупного проекта по рассматриваемой проблеме: «Российское крестьянство в эпоху революций и Гражданской войны: регионально-национальный аспект». Этот проект реализован при поддержке Российского фонда фундаментальных исследований под руководством В.А. Юрченкова и В.В. Кондрашина.

Особое внимание уделяется отражению в публикациях российских историков таких терминов и понятий крестьянского движения в годы Гражданской войны, как «Великая крестьянская война», «крестьянский фронт», «крестьянская революция». Автор критически относится к использованию при анализе повстанческого движения крестьян в данный период таких определений, как «партизанское движение», «партизанская борьба» и т. д., и предлагает свою классификацию форм крестьянских выступлений.

Рассматриваются также современные публикации российских исследователей о лидерах крестьянского повстанческого движения в России в годы Гражданской войны, влиянии на повстанцев партии эсеров, белого движения, а также природно-демографического и этнического факторов.
\end{abstract}

Ключевые слова: крестьянство, Гражданская война, крестьянское повстанческое движение, отечественная историография, терминология, просопография.

Цитирование. Кондрашин В.В. О достижениях и проблемах современной отечественной историографии крестьянского повстанческого движения в России в годы Гражданской войны // Вестник Самарского университета. История, педагогика, филология. 2018. Т. 24. № 1. С. 39-45 DOI: http://dx.doi.org/10.18287/2542-0445-2018-24-1-39-45.

This is an open access article distributed under the Creative Commons Attribution License Which permits unrestricted use, distribution, and reproduction in any medium, provided the original work is properly cited. (CC BY 4.0) 


\title{
ON ACHIEVEMENTS AND PROBLEMS OF MODERN DOMESTIC HISTORIOGRAPHY OF PEASANT RELIANCE MOVEMENT IN RUSSIA IN THE YEARS OF THE CIVIL WAR
}

(C) Kondrashin Viktor Viktorovich - Doctor of Historical Sciences, professor, chief scientific officer, head of the Center for Economic History, Institute of Russian History of the Russian Academy of Sciences, 19, Dmitry Ulyanov Street, Moscow, 117292, Russian Federation.

E-mail: vikont37@yandex.ru. ORCID: https://orcid.org/0000-0001-7552-9265

\begin{abstract}
The article analyzes the achievements and problems in the field of studying by Russian researchers of the history of peasant rebel movement in Russia during the Civil War.

The focus is research projects on the history of peasant movement in Russia during the Civil War of the Saratov historian A.V. Posadsky, who managed to combine historians from different regions to write three collective monographs on the subject.

The article describes the works of the project of the Russian Foundation for Basic Research «The Russian Peasantry in the Age of Revolutions and Civil War: Regional-National Aspect». They are prepared for publication by a team of regional historians under the leadership of V.A. Yurchenkova and V.V. Kondrashin. The author of the article concludes about the scientific significance of this project and the need for further study of the problem at the regional level.

Particular attention is paid in the article to the reflection in the publications of Russian historians of the terminology of peasant rebel movement during the Civil War. What was it: «The Great Peasant War», «peasant front», «peasant revolution»? Is it possible to use such definitions as «guerrilla movement», «partisan struggle» etc. during the analysis of the insurgent movement of peasants during this period?

The article analyzes the publications of contemporary Russian historians about the leaders of peasant rebel movement in Russia during the Civil War, points out the need for further study by researchers of such aspects of the problem as the influence on peasant uprisings of the party of Socialist-Revolutionaries and white regimes.

The author highlights the work of Russian researchers on the importance of natural and demographic factor in peasant performances in the Russian regions during the Civil War against the policy of Soviet government.
\end{abstract}

Key words: peasantry, Civil War, peasant rebel movement, domestic historiography, terminology, prosopography.

Citation. Kondrashin V.V. O dostizheniiakh i problemakh sovremennoi otechestvennoi istoriografii krest'ianskogo povstancheskogo dvizheniia $\mathrm{v}$ Rossii v gody Grazhdanskoi voiny [On achievements and problems of modern domestic historiography of peasant reliance movement in Russia in the years of the Civil War]. Vestnik Samarskogo universiteta. Istoriia, pedagogika, filologiia [Vestnik of Samara University. History, pedagogics, philology], 2018, Vol. 24, no. 1, pp. 39-45. DOI: http://dx.doi.org/10.18287/2542-0445-2018-24-1-39-45.

Настоящим прорывом в современных исследованиях истории крестьянского движения в России в годы Гражданской войны стали научные проекты саратовского историка А.В. Посадского, сумевшего объединить для написания коллективных монографий на данную тему историков различных регионов страны. В результате опубликованы коллективные монографии, где впервые в историографии дан комплексный и сравнительно-исторический анализ всех наиболее известных фактов крестьянского повстанчества в России в годы Гражданской войны. Кроме того, в них сделан акцент на персоналии (просопографию) лидеров и участников крестьянского движения [«Атаманщина» и «партизанщина»...; Крестьянский фронт 1918-1922 гг.].

Также заслуживают внимания издания проекта РФФИ «Российское крестьянство в эпоху револю- ций и Гражданской войны: регионально-национальный аспект», подготовленные к печати коллективом региональных историков под руководством В.А. Юрченкова и В.В. Кондрашина. В них представлена панорама крестьянского и казачьего повстанческого движения в России в 1917-1922 гг. на основе анализа разнообразных и достоверных источников [Крестьянство и казачество России...; Осипова].

Заметным явлением в историографии проблемы стала международная научная конференция 20 мая 2017 г. в Тамбове, посвященная крестьянскому восстанию в Тамбовской губернии под руководством А.С. Антонова. Фактически на ней подведены итоги изучения крестьянского повстанчества в годы Гражданской войны и определены дальнейшие перспективы в исследовании проблемы с использованием 
Кондрашин В.В.

О достижениях и проблемах современной отечественной историографии...

новых методик и источников [Крестьянское восстание в Тамбовской губернии...].

В современной историографии аграрная политика большевиков в годы Гражданской войны изучается в общем контексте истории крестьянского повстанческого движения как его важнейший аспект при характеристике причин повстанчества, а также в контексте более крупной проблемы «крестьянство и власть». Чисто «экономических работ», оторванных от данных контекстов, очень мало. В связи с этим до настоящего времени не потеряла своей актуальности и научной значимости монография В.В. Кабанова о крестьянском хозяйстве в условиях «военного коммунизма» [Кабанов]. В ней убедительно показано негативное влияние этой политики на сельское хозяйство страны. Она разоряла крестьянские хозяйства, делала неизбежным конфликт крестьянства с советской властью.

То, что аграрная политика большевиков являлась главной причиной крестьянского повстанчества, следует из работ О.А. Суховой, В.А. Юрченкова, Н.В. Липатовой и др. Хотя они не посвящены непосредственно теме крестьянского повстанческого движения, но содержащийся в них анализ издержек новой системы управления в деревне и практики создания и функционирования Советов и коммун, а также особенностей региональной аграрной политики красноречиво объясняет причины крестьянского протеста [Крестьянство и казачество России..., с. 365-393, 398-425].

Высокой оценки, на наш взгляд, заслуживают публикации С.А. Нефедова, где затрагивается тема уровня жизни крестьян в годы Гражданской войны. Автор указывает на его резкое снижение в результате политики продразверстки большевиков, приведшей в конечном итоге к голоду 19211922 гг. [Нефедов, с. 149-155].

В то же время, полагаем, при всех издержках политики «военного коммунизма» советской власти она не имела своей целью «государственный геноцид», как считают некоторые исследователи [Крестьянство и казачество России..., с. 433].

В целом чисто экономический аспект проблемы крестьянского движения в годы Гражданской войны заслуживает более пристального внимания исследователей, особенно на региональном и микроуровнях: уездном, волостном, семейном [Крестьянское восстание в Тамбовской губернии..., с. 42].

Новым и позитивным моментом в развитии историографии проблемы на современном этапе стал интерес исследователей к персоналиям - конкретным участникам и вождям крестьянского повстанчества («атаманам», «вожакам» и т. д.). Особенно, по нашему мнению, заслуживают внимания вышеупомянутые публикации на данную тему историков и краеведов, выполненные в рамках проектов А.В. Посадского («Атаманщина» и партизанщина в Гражданской войне» и «Крестьянский фронт 1918-1922 гг.»), а также целевого конкурса РФФИ под руководством В.А. Юрченкова и В.В. Кондрашина («Российское крестьянство в эпоху революций и Гражданской войны: регионально-национальный аспект»). В них представлены биографические очерки руководителей крестьянского повстанчества в различных регионах страны в 1918-1922 гг. [«Атаманщина» и «партизанщина»...; Крестьянский фронт 1918-1922 гг.; Кресть- янство и казачество России...; Российское крестьянство в эпоху революций и Гражданской войны].

Так, А.В. Посадский, характеризуя лидеров крестьянского движения, обращает внимание на факт наличия в каждом крупном повстанческом формировании фигуры «идеолога», как правило, полуинтеллигента с эсеровским стажем [Крестьянство и казачество России..., с. 781]. По его мнению, при изучении данного аспекта «повстанщины» необходимо учитывать и криминальный тип ряда крестьянских вожаков как один из вариантов «военного вожачества» «с нефункциональной жестокостью» [Крестьянство и казачество России..., с. 781]. Он же акцентировал внимание исследователей на «феномене фронтовика» - участников Первой мировой войны, которые нередко возглавляли антибольшевистские восстания (напр., Ижевско-Воткинское восстание в августе-ноябре 1918 г. в Удмуртии) [Крестьянство и казачество России..., с. 782-787].

П.П. Щербинин поставил вопрос о восприятии крестьянами своих вожаков на примере отношения тамбовских крестьян к А.С. Антонову и его сподвижникам [Крестьянство и казачество России..., c. 787-795]. Он заключает, что народный фольклор в целом дает «положительную трактовку участников крестьянского движения», фиксирует даже факт «восхищения» вожаком и участниками восстания [Крестьянство и казачество России..., с. 791]. В то же время П.П. Щербинин, на наш взгляд, прав, когда утверждает, что Антонова «нельзя признать классическим народным вожаком, который руководствовался только благородными чувствами защитника крестьян». Он был «политическим деятелем», который вместе с другими лидерами антоновщины так и не смог преодолеть «свои политические амбиции и корыстный интерес», что «в конце концов поняли рядовые участники движения и поддерживавшие их крестьяне» [Крестьянство и казачество России..., с. 794].

Этот вывод конкретизирован автором анализом отношения крестьян к уголовникам и дезертирам с «эсеровским душком», активно участвовавшим в антоновщине. Для крестьян они «были чужими». Бандитов в деревне не любили издавна, считая их тунеядцами. Отсюда негативное восприятие подобных людей из окружения Антонова. К дезертирам же крестьяне относились снисходительнее, так как уход в леса был «вполне традиционной формой крестьянского протеста». Однако на заключительном этапе антоновщины большинство крестьян уже не воспринимало их как «своих» и относилось к ним с достаточной долей подозрения, отождествляя их с «лихим людом» [Крестьянство и казачество России..., с. 795]. Отсюда и закономерный итог восстания.

Анализ П.П. Щербинина фактически подтвердил Д.П. Иванов. Он представил исторические портреты антоновского окружения (И.Е. Ишина, Г.Н. Плужникова, П.И. Сторожева и др.) и пришел к выводу, что в окружении Антонова на всем протяжении Тамбовского восстания было достаточное количество одаренных людей, обладавших харизмой и способных увлечь за собой крестьянские массы. Однако в отличие от своих противников - большевиков - лидеры крестьянского восстания «не смогли преодолеть свои политические амбиции и корыстный интерес». Стремление к достижению личных целей, а не к выступлению единой силой в конечном итоге и привело к поражению восстания, констатирует исследователь [«Атаманщина» и «партизанщина»..., с. 465-477]. 
Значительный вклад в изучение просопографии вожаков антоновщины вносит группа тамбовских исследований во главе с В.В. Канищевым. В настоящее время тамбовские историки в рамках проекта по применению междисциплинарных подходов к изучению позднего аграрного общества России приступили к созданию электронной базы данных не только о вожаках и участниках Антоновского восстания, но и других крестьянских протестных выступлений в регионе периода с 1860-1920 гг. Уже введены в ЭВМ несколько тысяч записей и проведены первые эксперименты по их обработке [«Атаманщина» и «партизанщина»..., с. 21]. В результате подтвержден факт перехода части советских служащих и революционных партийцев на сторону повстанцев в 1918-1922 гг. и превращения их в активистов восстания [«Атаманщина» и «партизанщина»..., с. 28].

В современной литературе на тему крестьянских вожаков имеются очень интересные и насыщенные достоверным материалом публикации. К их числу, например, относится очерк К.И. Соколова о Фроле Белякове - лидере крестьянского повстанческого движения в Тверской губернии в годы Гражданской войны [«Атаманщина» и «партизанщина»..., с. 588-602]. В 1918 г. Фрол Беляков возглавил крестьянское восстание в селе Молодой Туд Ржевского уезда Тверской губернии. Затем в начале 1920-х гг. он вернулся в родные края, «чтобы мстить коммунистам» [«Атаманщина» и «партизанщина»..., с. 588].

На современном этапе исследования проблемы в центре внимания историков остаются вопросы методологии и источниковедения. Так, нуждается в дальнейшем осмыслении терминология проблемы. Например, как наиболее точно определить суть крестьянского движения в России в годы Гражданской войны. Что это было: «Великая крестьянская война», «крестьянский фронт», «крестьянская революция»? Корректно ли использование при анализе повстанческого движения крестьян определений «партизанское движение», «партизанская борьба» и т. д.? Каковы критерии классификации форм крестьянских выступлений? Что такое «восстание», «выступление», «мятеж», «атаманщина», «партизанщина» и т. д.?

Поставленные вопросы нашли отражение в публикациях ведущих специалистов по рассматриваемой проблеме. В частности, термин «крестьянский фронт», введенный в научный оборот Т.В. Осиповой, поддерживает А.В. Посадский [Крестьянский фронт 19181922 гг. ..., Нефедов]. Ему принадлежит наиболее полное объяснение данного термина: «Крестьянский фронт в годы Гражданской войны - это не только повстанческое «не белое и не красное» движение и всякого рода бунты и волнения без определенной политической окраски. Это - в целом поведение крестьянина в Гражданской войне. И отношение к противоборствующим армиям, к мобилизации, к центральной и местной власти, стереотипы поведения на войне, в критических условиях, при перспективе покинуть родные края, готовность или нежелание отдавать ресурсы борюшимся сторонам [Крестьянский фронт 1918-1922 гг. ..., с. 15].

Д.А. Сафонов называет крестьянские выступления против политики большевиков в 1920-1921 гг. «Великой крестьянской войной» [Сафонов]. В.В. Канищев квалифицирует их как «третью силу», «третий путь» в Гражданской войне, который «торили народные вожаки» [Крестьянский фронт 1918-1922 гг. ..., с. 21].
С приведенными оценками категорически не согласен А.А. Куренышев. Он против сравнения антоновщины с «крестьянской войной» «наподобие «пугачевщины» и «восстания Степана Разина». Также он считает неправомерным рассуждения историков о «крестьянском фронте» против советской власти как едином, «простиравшимся от Сибири до Украины». В этом случае в его состав следовало бы включить «даже ближнее и дальнее Подмосковье, Владимировскую, Ярославскую и Рязанскую губернии», иронизирует историк. По его мнению, такой «терминологической игрой» авторы стремились «усилить, увеличить роль и значение событий 1921-1922 гг. в Тамбовской губернии» [Крестьянское восстание в Тамбовской губернии..., с. 47-50].

А.А. Куренышев считает, что «единого крестьянского фронта» не могло быть по причине разных политических ориентаций повстанцев, поскольку Антонов стремился к союзу с белыми, а Махно - с анархистами. Поэтому, по его мнению, корректнее говорить о «едином фронте» крестьянского повстанческого движения с антибольшевистским фронтом в Гражданской войне [Крестьянское восстание в Тамбовской губернии..., с. 47-50].

С такой же категоричностью А.А. Куренышев выступает против использования при анализе крестьянского движения концепции «крестьянской революции» В.П. Данилова, считая, что достижение крестьянами в 1917 г. их основной цели - ликвидации помещичьего землевладения - не остановило их конфликт с властью по поводу «вечного для мелкого производителя вопроса» о ценах на свою продукцию [Крестьянское восстание в Тамбовской губернии..., с. 48-49].

На наш взгляд, А.А. Куренышев прав в части критики сторонников терминологии «крестьянский фронт», «Великая крестьянская война», которая действительно носит эмоциональный характер и связана со стремлением исследователей показать значительные масштабы крестьянского движения в годы Гражданской войны. Что же касается критики А.А. Куренышевым концепции «крестьянская революция», то здесь, на наш взгляд, налицо его недопонимание сути этой концепции. А она состоит в том, что после победы «общинной революции» в 1917 г. крестьяне всю Гражданскую войну отстаивали право на полученную землю в ходе этой «общинной революции» своим противостоянием с большевистской властью, ее политикой «военного коммунизма». И они отстояли его, заставив большевиков ввести нэп и законодательно закрепить право на землю в Земельном кодексе РСФСР 1922 г.

Тамбовский историк Д.И. Иванов подверг критике использование исследователями при анализе крестьянских выступлений в годы Гражданской войны терминов «партизанская война», «партизанская борьба». Также он внес ясность в понятие «атаманщина», определив ее как один из этапов крестьянского восстания в Тамбовской губернии в 1919-1921 гг. Само восстание историк назвал повстанчеством по аналогии с крестьянским повстанчеством в XX веке в Латинской Америке [Крестьянское восстание в Тамбовской губернии..., с. 36-40].

На наш взгляд, можно согласиться с его аргументацией неправомерности использования термина «партизанская война». Д.И. Иванов указывает: «Партизанская война - это одна из форм борьбы против 
Кондрашин В.В.

О достижениях и проблемах современной отечественной историографии...

иноземных захватчиков, составная часть войны, которая ведется на территории, контролируемой неприятелем, и способами, отличными от действий регулярных войск. Тамбовское восстание по форме напоминало партизанскую войну. Однако главным противником тамбовских крестьян все же выступало свое правительство. Боевые действия происходили на территории, подконтрольной советской власти, а в конфликте не были замешаны иностранные вооруженные силы. Поэтому мы не можем отнести события в Тамбовской губернии в 1918-1920 гг. к традиционной партизанской войне, поскольку они противоречат ее основным признакам» [Крестьянское восстание в Тамбовской губернии..., с. 36-37].

Рассмотрев различные интерпретации антоновщины, Д.И. Иванов сделал следующие выводы. Крестьянское движение в Тамбовской губернии в 1920-1921 гг., по сути, являлось повстанчеством, «каждый этап которого принимал разнообразные формы, которые соответствовали конкретной исторической обстановке отдельных отрезков периода второй половины $1920-$ первой половины 1921 г.». Зарождение движения и оформление его идеологического ядра пришлось на расцвет бандитизма и начала «зеленого движения». Террористический этап, в ходе которого окончательно оформился костяк будущей Партизанской армии Тамбовского края, по времени совпал с подъемом движения «зеленых». Начало третьего этапа - непосредственно самой антоновщины, периода «атаманщины» - совпало с ростом массовых крестьянских выступлений и спадом дезертирского движения [Крестьянское восстание в Тамбовской губернии..., с. 39].

По нашему мнению, позиция Д.И. Иванова заслуживает поддержки. И крестьянское движение в России в годы Гражданской войны следует называть крестьянским повстанческим движением, имевшим разные формы и региональные особенности.

В данном контексте перед исследователями остается не решенной до конца задачей учет и классификация крестьянских выступлений (крестьянского движения) в рассматриваемый период. На это указал в своих публикациях А.В. Посадский. В них, как уже отмечалось, он отдает предпочтение анализу событий крестьянского повстанчества в годы Гражданской войны в терминологии «крестьянский фронт» «атаманщина», «партизанская борьба» и т. п. [Крестьянство и казачество России..., с. 717-726].

По нашему мнению, при характеристике конкретных форм крестьянского повстанчества в изучаемый период необходимо точно определять их конкретноисторическое содержание, основанное на достоверных знаниях. Исходя из этого принципа, автором настоящей статьи предложена своя классификация крестьянских выступлений (крестьянского повстанческого движения) в годы Гражданской войны. Она основана на результатах изучения проблемы на материалах Поволжья и Украины.

Под повстанческим движением мы понимаем операции вооруженных отрядов, групп восставших крестьян, действующих в одном или нескольких уездах, одной или нескольких губерниях, выдвигающих политические лозунги и осуществляющих их на практике, а также и другие мероприятия в интересах подавляющего большинства населения подконтрольной им зоны.
Формами крестьянского повстанчества в 19181922 гг. в Поволжье были: «восстание», «волнение», «выступление», «мятеж».

Высшей формой повстанчества является «восстание», под которым нами понимается форма выступления с высоким уровнем сознательности участников. В ходе восстания восставшие самостоятельно планируют свои действия, сами выбирают стиль своего поведения. Восстание начинается по инициативе широких слоев населения, по их собственному почину; для восставших вооруженная борьба - заранее намеченный пункт деятельности. Кроме того, к названным характеристикам следует добавить и такие, как: массовость движения, охват им территории не менее нескольких уездов; относительная продолжительность движения (как правило, не менее месяца); использование против восставших значительных сил «карателей».

Волнение - это более низкий уровень активного протеста крестьянства: как правило, его участниками являются крестьяне одного или нескольких селений, в ходе волнения может применяться или не применяться насилие по отношению к представителям власти, оно может быть ликвидировано без использования вооруженной силы, по продолжительности может быть незначительным (всего нескольких дней).

Выступление - это понятие, характеризующее единичный факт крестьянской активности, более низкой, чем волнение и восстание. Как правило, в нем участвует группа крестьян одного селения или селение в целом, оно ликвидируется без применения вооруженной силы, является кратковременным по сроку, не имеет тяжких последствий для участников.

В то же время не всегда существует четкая грань между восстанием и волнением, волнением и выступлением. В ряде случаев эти понятия совпадают и вполне могут использоваться для характеристики факта крестьянской активности.

Под термином «мятеж» автор статьи подразумевает антиправительственное выступление воинского формирования, поддержанное крестьянским населением [Кондрашин, с. 76-77].

Вопросы понятийного аппарата крестьянского движения в России в годы Гражданской войны по-прежнему остаются актуальными и дискуссионными для современных исследователей.

Но в любом случае при выборе того или иного понятия для характеристики крестьянского движения необходима опора на достоверные источники. Проблема источников - одна из ключевых для исследователей данной темы. К настоящему времени в рамках монографических и коллективных работ, документальных серий в научный оборот введен огромный массив источников. В большинстве своем это документы и материалы советских гражданских и военных органов, задействованных в борьбе с крестьянским повстанчеством. Среди них и документы самих повстанцев (воззвания, программы, уставы и т. д.), ставшие трофеями после подавления крестьянских выступлений.

Поиск новых документов по рассматриваемой проблеме и их анализ с помощью нетрадиционных методов и технологий - важнейшее направление в работе исследователей. И они успешно идут по этому пути. Например, В.Л. Дьячков указывает на значение и важность крестьянских свидетельств при изучении проблемы [Крестьянское восстание в Тамбовской губер- 
нии..., с. 27-32]. А.Н. Грищенко акцентирует внимание на письмах крестьян родственникам, мобилизованным в Красную армию, где содержатся ценные сведения на тему причин крестьянского повстанчества [Крестьянское восстание в Тамбовской губернии..., c. 55-60]. Г.Г. Болтнев считает важным поиск семейных документов, чтобы освещать повстанчество «через призму судьбы семьи» [Крестьянское восстание в Тамбовской губернии..., с. 13-16]. В.П. Середа указывает на русскоязычную зарубежную прессу начала 1920-х гг. как на источник о крестьянском восстании на Тамбовщине» [Крестьянское восстание в Тамбовской губернии..., с. 101-104]. Г.К. Гольцева напоминает о важности правильного «археографического прочтения мемуаров старых большевиков» [Крестьянский фронт 1918-1922 гг. ..., с. 48-69]. В.В. Канищев предлагает шире использовать материалы местных газет и газет воинских частей, участвовавших в подавлении атоновшины [Крестьянское восстание в Тамбовской губернии..., с. 43].

В то же время А.Г. Тепляков справедливо указывает, что при характеристике «теневых сторон» повстанчества (партизанщины) необходимо учитывать факт наличия «многочисленных фальсифицированных источников и необъективных исследований», появившихся «под идеологическим прессингом», особенно когда речь идет о мемуарах и документах большевиков. Он считает, что исследователями недооценен такой вид источника, как документы антибольшевистских властей и сообщения белой прессы. В них воспроизведены «наиболее жуткие и вместе с тем информативные эпизоды» расправ повстанцев над священнослужителями, пленными и т. д., которые не всегда отражены в советских документах [«Атаманщина» и «партизанщина»..., с. 31-39].

Очень важную проблему, требующую использования новых источников и нетрадиционных методов их изучения, поднимает тамбовский историк В.В. Канищев [«Атаманщина» и «партизанщина»..., с. 20-30]. Как уже отмечалось, он и его коллеги установили зависимость степени партизано-повстанческой активности «от кормящего ландшафта», «от типов характеров, рождающихся в том или ином варианте земледельческого состояния» [«Атаманщина» и «партизанщина»..., с. 488]. Данная проблематика разрабатывается тамбовскими исследователями в рамках «социоестественной истории» (на материалах Тамбовской губернии) [Иванов, Канищев]. Ее изучение перспективно с точки зрения ответа на дискуссионный вопрос о причинах разной степени повстанческой активности крестьян в годы Гражданской войны в различных регионах страны. Почему «глобальные» природно-демографические кризисы традиционного общества не по всей Европейской России приводили к массовой крестьянской агрессии против власти? Почему крестьянское восстание в 1920-1921 гг. происходило не на всей территории Тамбовской губернии [Крестьянское восстание в Тамбовской губернии..., с. 40-44].

В.В. Канищев обоснованно предлагает при изучении крестьянского движения в России в годы Гражданской войны учитывать «этнический и субэтнический типы конфронтационного поведения», «градус» готовности крестьян к участию в силовом противостоянии. Он верно заключает: «Будь то пассионарность биологического или информационного происхождения, она позволяет себя обнаружить в локальных самоорганизациях крестьян из бывших казаков (иногородние на Кубани из запорожцев, прихопер- ские села, понимавшие себя как казаки, несмотря на крестьянскую сословную принадлежность, и т. д.), староверов, крестьян-однодворцев и т. П.» [Крестьянский фронт 1918-1922 гг. ..., с. 16-17]. Подобный взгляд на проблему требует междисциплинарного подхода и новых источников.

Они необходимы и при решении проблемы численности участников крестьянских выступлений в годы Гражданской войны в конкретных регионах. В частности, по мнению В.В. Канищева, для получения более точных данных в современных условиях «можно и нужно использовать геоинформационные технологии» [Крестьянское восстание в Тамбовской губернии..., с. 42].

Как показывает анализ современной историографии проблемы, по-прежнему актуальным остается и ряд вопросов, связанных с характеристикой таких аспектов крестьянского повстанческого движения в России в годы Гражданской войны, как соотношение стихийности и сознательности в крестьянском повстанчестве, влиянии на него внешних сил [Люкшин].

На этот факт указал в своих исследованиях А.В. Двойных. Он отстаивает тезис, что крестьянское повстанческое движение в России в его эпицентрах имело политическую программу, которая была выражена в лозунгах повстанцев и их программных документах, и ее нельзя назвать «примитивной» [Двойных]. Его позиция выглядит убедительно, поскольку основана на анализе многочисленных лозунгов, воззваний, агитационно-пропагандистских материалов «антоновщины», «чапанной войны», «Западно-Сибирского восстания» и других крупнейших выступлений крестьянства России в годы Гражданской войны против большевистской власти. Автор настоящей статьи также разделяет эту точку зрения [Кондрашин, с. 255276; Крестьянский фронт 1918-1922 гг. ..., с. 80-98].

В рамках обозначенной проблемы в историографии обсуждается вопрос о влиянии на крестьянское движение партии эсеров и белого движения: в выработке лозунгов и программных документов, организации восстаний и т. д. Ряд исследователей не отрицает факт такого влияния, но считает, что оно не было решающим для крестьянства. Так, например, В.Б. Безгин, анализируя лозунги повстанчества на Тамбовщине, заключает: «...лозунг партии эсеров “В борьбе обретешь ты право свое!”, взятый на вооружение тамбовскими повстанцами, отнюдь не свидетельствовал о руководящей роли этой партии, а лишь выражал готовность крестьян силой отстаивать свое право свободно распоряжаться результатами своего труда» [Крестьянское восстание в Тамбовской губернии..., с. 10-13]. Аналогичную ситуацию исследователи увидели и в других эпицентрах крестьянского повстанчества, где крестьяне использовали эсеровские или анархистские лозунги для выражения его целей, но в целом повстанчество было «стихийным» и чисто «крестьянским» [Кондрашин, с. 302-315].

Тем не менее тема взаимосвязи крестьянских восстаний с эсерами, анархистами и белыми армиями нуждается в дальнейшем изучении, поскольку эта взаимосвязь существовала. И оно необходимо, учитывая ряд категоричных суждений современных исследователей.

Так, А.А. Куренышев в категоричной форме выступил против утвердившегося в историографии тезиса о «стихийности» крестьянского повстанчества в 1920-1922 гг. В частности, он заключил, что поскольку все крупные крестьянские восстания в России против политики большевиков в годы Гражданской войны 
Кондрашин В.В.

О достижениях и проблемах современной отечественной историографии...

так или иначе были организованы политическими партиями и с участием белого движения, то концепция их «стихийности» «должна быть подвергнута серьезному анализу, переосмыслению и критике» [Крестьянское восстание в Тамбовской губернии..., с. 79; Куренышев].

Таковы лишь некоторые аспекты истории крестьянского повстанческого движения в России в годы Гражданской войны. Их анализ свидетельствует о необходимости дальнейшего изучения данной темы, особенно на региональном уровне и с привлечением новых источников. Это позволит лучше понять феномен крестьянства в истории России XX века.

\section{Библиографический список}

«Атаманщина» и «партизанщина» в Гражданской войне: идеология, военное участие, кадры: сб. статей и материалов / под ред. А.В. Посадского. М.: АИРО XXI, 2015. $856 \mathrm{c}$.

Двойных А.В. Лозунги и программа крестьянского повстанчества в России в годы Гражданской войны: дис. ... канд. ист. наук. Пенза, 2010. 190 с.

Иванов Д.П., Канищев В.В. Естественноисторические предпосылки Тамбовского восстания 1920-1921 гг.: учебное пособие. Тамбов, 2011. 55 с.

Кабанов В.В. Крестьянское хозяйство в условиях военного коммунизма. М.: Наука, 1988. 305 с.

Кондрашин В.В. Крестьянство России в Гражданской войне: к вопросу об истоках сталинизма. М.: РОССПЭН, 2009. 575 с.

Крестьянский фронт 1918-1922 гг.: сб. статей и материалов / сост. и науч. ред. А.В. Посадский. М.: АИРО - ХХІ, 2013. 740 с.

Крестьянское восстание в Тамбовской губернии под руководством А.С. Антонова (1920-1921 гг.): материалы международной научной конференции (г. Тамбов, 20 мая 2017 года) // Исторические, философские, политические и юридические науки, культурология и искусствоведение. Вопросы теории и практики. 2017. № 6 (80): в 2 ч. Ч. 2.118 с.

Крестьянство и казачество России в условиях революции 1917 г. и Гражданской войны: национальнорегиональный аспект. / отв. ред. В.В. Кондрашин, В.А. Юрченков. М.; Саранск, 2017. 1048 с.

Куренышев А.А. Крестьянские военно-политические организации России. Повстанчество. 1918-1922 гг. М.: Спутник. 2010. 172 с.

Люкшин Д.И. Вторая русская смута: крестьянское измерение. М., 2006. 144 с.

Нефедов С.А. Уровень жизни населения и аграрное

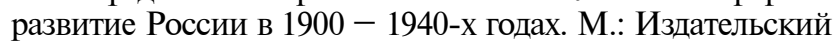
дом «Дело» РАНХиГС, 2017. 432 с.

Осипова Т.В. Крестьянский фронт в Гражданской войне // Судьбы российского крестьянства. М, 1995. С. 90-162.

Российское крестьянство в эпоху революций и Гражданской войны: регионально-национальный аспект: сб. документов / отв. ред. В.В. Кондрашин, В.А. Юрченков). Саранск: НИИ гуманитарных наук при Правительстве Республики Мордовия, 2016. 880 с.

Сафонов Д.А. Великая крестьянская война 19201921 гг. и Южный Урал. Хроника и Историография. Оренбург, 1999. 314 с.

\section{References}

«Atamanshchina» $i$ «partizanshchina» $v$ Grazhdanskoi voine: ideologiia, voennoe uchastie, kadry. Sbornik statei i materialov.
Pod red. A.V. Posadskogo [«Atamanshchina» and «guerilla warfare» in the Civil War: ideology, military participation, cadres. Collection of articles and materials. A.V. Posadsky (Ed.)]. M.: AIRO - XXI, 2015, 856 p. [in Russian].

Dvoiniyh A.V. Lozungi i programma krest'ianskogo povstanchestva $v$ Rossii v gody grazhdanskoi voiny: dis. ... kand. ist. nauk [Slogans and the program of peasant insurrection in Russia during the Civil War: Candidate's of Historical Sciences thesis]. Penza, 2010, 190 p. [in Russian].

Ivanov D.P., Kaishev V.V. Estestvenno-istoricheskie predposylki Tambovskogo vosstaniia $1920-1921$ gg. Uchebnoe posobie [Natural historical background of the Tambov uprising of 1920-1921. Tutorial]. Tambov, 2011, 55 p. [in Russian].

Kabanov V.V. Krest'ianskoe khoziaistvo $v$ usloviiakh voennogo kommunizma [Peasant farming in the conditions of war communism]. M.: Nauka, 1988, 305 p. [in Russian].

Kondrashin V.V. Krest'ianstvo Rossii v Grazhdanskoi voine: $k$ voprosu $o b$ istokakh stalinizma [The peasantry of Russia in the Civil War: on the issue of the origins of Stalinism]. M.: ROSSPEN, 2009, 575 p. [in Russian].

Krest'ianskii front $1918-1922 \mathrm{gg}$. Sbornik statei i materialov. Sost. i nauch. red. A.V. Posadskii [Peasant Front of 1918-1922. Collection of articles and materials. Complier and scientific editor A.V. Posadsky]. M.: AIRO - XXI, 2013, 740 p. [in Russian].

Krest'ianskoe vosstanie $v$ Tambovskoi gubernii pod rukovodstvom A.S. Antonova (1920-1921 gg.). Materialy mezhdunarodnoi nauchnoi konferentsii (g. Tambov, 20 maia 2017 goda) [Peasant uprising in the Tambov province under the leadership of A.S. Antonov (1920-1921). Materials of the International Scientific Conference (Tambov, May 20, 2017)]. In: Istoricheskie, filosofskie, politicheskie i iuridicheskie nauki, kul'turologiia $i$ iskusstvovedenie. Voprosy teorii i praktiki [Historical, philosophical, political and legal sciences, culturology and art history. Issues of theory and practice], 2017, no. 6 (80): in 2 parts. Part 2. 118 p. [in Russian].

Krest'ianstvo i kazachestvo Rossii $v$ usloviiakh revoliutsii 1917 g. i grazhdanskoi voiny: natsional'no-regional'nyi aspekt. Otv. red. V.V. Kondrashin, V.A. Iurchenkov [The peasantry and the Cossacks of Russia in the conditions of the 1917 revolution and the Civil War: national-regional aspect. V.V. Kondrashin, V.A. Yurchenkov (Eds.)]. M.; Saransk, 2017, 1048 p. [in Russian].

Kurenishev A.A. Krest'ianskie voenno-politicheskie organizatsii Rossii. Povstanchestvo. 1918-1922 gg. [Peasants' military-political organizations of Russia. Insurgency. 1918-1922]. M.: Sputnik, 2010, 172 p. [in Russian].

Lyukshin D.I. Vtoraia russkaia smuta: krest'ianskoe izmerenie [Second Russian revolt: peasant dimension]. M., 2006, 144 p. [in Russian].

Nefedov S.A. Uroven' zhizni naseleniia $i$ agrarnoe razvitie Rossii v 1900 - 1940-kh godakh [Standard of living and agricultural development of Russia in 1900-1940-ies]. M.: Izdatel'skii dom «Delo» RANKhiGS, 2017, 432 p. [in Russian].

Osipova T.V. Krest'ianskii front $v$ grazhdanskoi voine [Peasant front in the Civil War]. In: Sud'by rossiiskogo krest'ianstva [The fate of Russian peasantry]. M, 1995, p. 90162 [in Russian].

Rossiiskoe krest'ianstvo $v$ epokhu revoliutsii i grazhdanskoi voiny: regional'no-natsional'nyi aspekt. Sbornik dokumentov. Otv. redaktory V.V. Kondrashin, V.A. Iurchenkov [Russian peasantry in the era of revolutions and Civil War: regionalnational aspect. Collection of documents. V.V. Kondrashin, V.A. Yurchenkov (Eds.)]. Saransk: NII gumanitarnykh nauk pri Pravitel'stve Respubliki Mordoviia, 2016, 880 p. [in Russian].

Safonov D.A. Velikaia krest'ianskaia voina 1920-1921 gg. i Iuzhnyi Ural. Khronika i Istoriografiia [The Great Peasant War of 1920-1921 and the Southern Urals. Chronicle and Historiography]. Orenburg, 1999, 314 p. [in Russian]. 